\title{
Archaeological Survey of the Proposed Road Improvements at the Lyndon B. Johnson National Historical Park, Johnson City, Gillespie County, Texas
}

Kristi M. Ulrich

Follow this and additional works at: https://scholarworks.sfasu.edu/ita

Part of the American Material Culture Commons, Archaeological Anthropology Commons, Environmental Studies Commons, Other American Studies Commons, Other Arts and Humanities Commons, Other History of Art, Architecture, and Archaeology Commons, and the United States History Commons

Tell us how this article helped you.

This Article is brought to you for free and open access by the Center for Regional Heritage Research at SFA ScholarWorks. It has been accepted for inclusion in Index of Texas Archaeology: Open Access Gray Literature from the Lone Star State by an authorized editor of SFA ScholarWorks. For more information, please contact cdsscholarworks@sfasu.edu. 


\section{Archaeological Survey of the Proposed Road Improvements at the Lyndon B. Johnson National Historical Park, Johnson City, Gillespie County, Texas}

\section{Creative Commons License}

\section{(c) (1) (8)}

This work is licensed under a Creative Commons Attribution-NonCommercial 4.0 International License 


\section{Archaeological Survey of the Proposed Road Improvements at the Lyndon B. Johnson National Historical Park, Johnson City, Gillespie County, Texas}

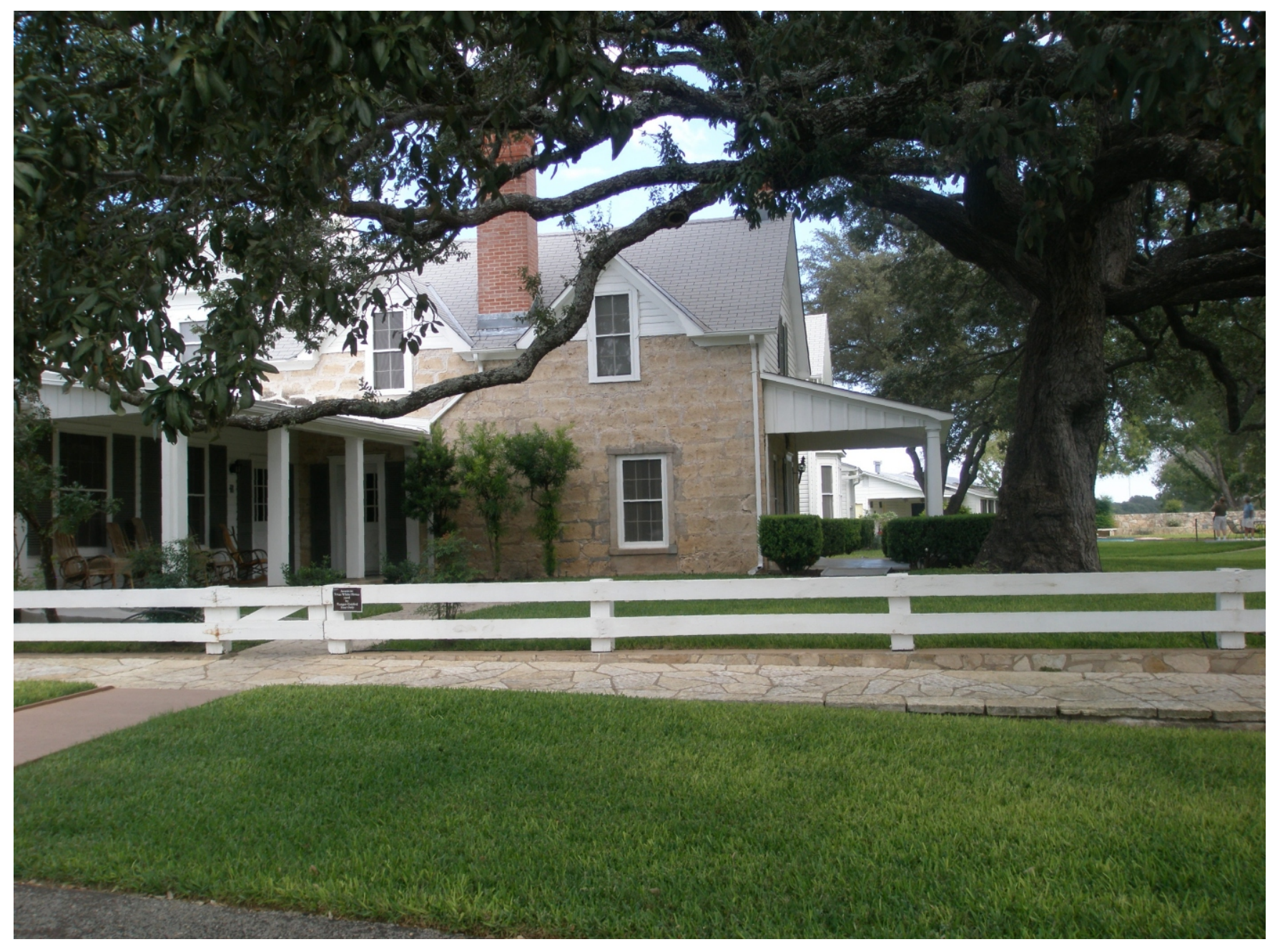

by

Kristi M. Ulrich

Prepared for:

The National Park Service

Lyndon B. Johnson National Historical Park

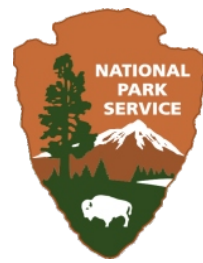

Prepared by:

Center for Archaeological Research The University of Texas at San Antonio Archaeological Report, No. 408

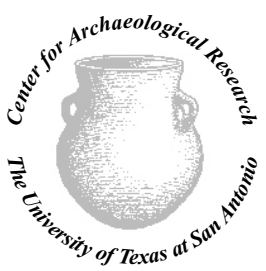





\title{
Archaeological Survey of the Proposed Road Improvements at the Lyndon B. Johnson National Historical Park, Johnson City, Gillespie County, Texas
}

\author{
by
}

Kristi M. Ulrich

Principal Investigator

Steve A. Tomka

\section{Prepared for:}

The National Park Service

Lyndon B. Johnson National Historical Park

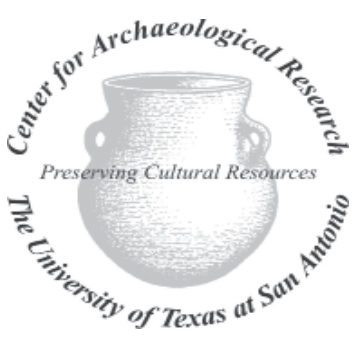

Center for Archaeological Research The University of Texas at San Antonio Archaeological Report No. 408 



\begin{abstract}
:
In September of 2009, CAR was contracted by the National Park Service Lyndon B. Johnson National Historical Park to conduct a pedestrian survey along the routes of the proposed improvements to two park roads: Bailey Road and Davis Road. Thirty shovel tests were excavated during the linear survey. Of these 30 shovel tests, seven produced cultural material. The material encountered consisted of lithic flakes and metal fragments. One multi-component site was designated during the course of the project. Site 41 GL411 produced a few flakes, rusted unidentifiable metal fragments, a fencing staple and slag. CAR recommends that the site's mixed deposits are not eligible for listing to the National Register of Historic Places nor warrant formal designation as a State Archaeological Landmark. A small portion of previously recorded site 41GL319 was encountered during the survey. One shovel test located within the site boundary produced one lithic flake. Two isolated finds were recorded during the project.
\end{abstract}

Dr. Steve Tomka served as Principal Investigator. All artifacts collected were processed at the CAR laboratory, and returned to the Lyndon B. Johnson National Historical Park for final curation. 


\section{Table of Contents:}

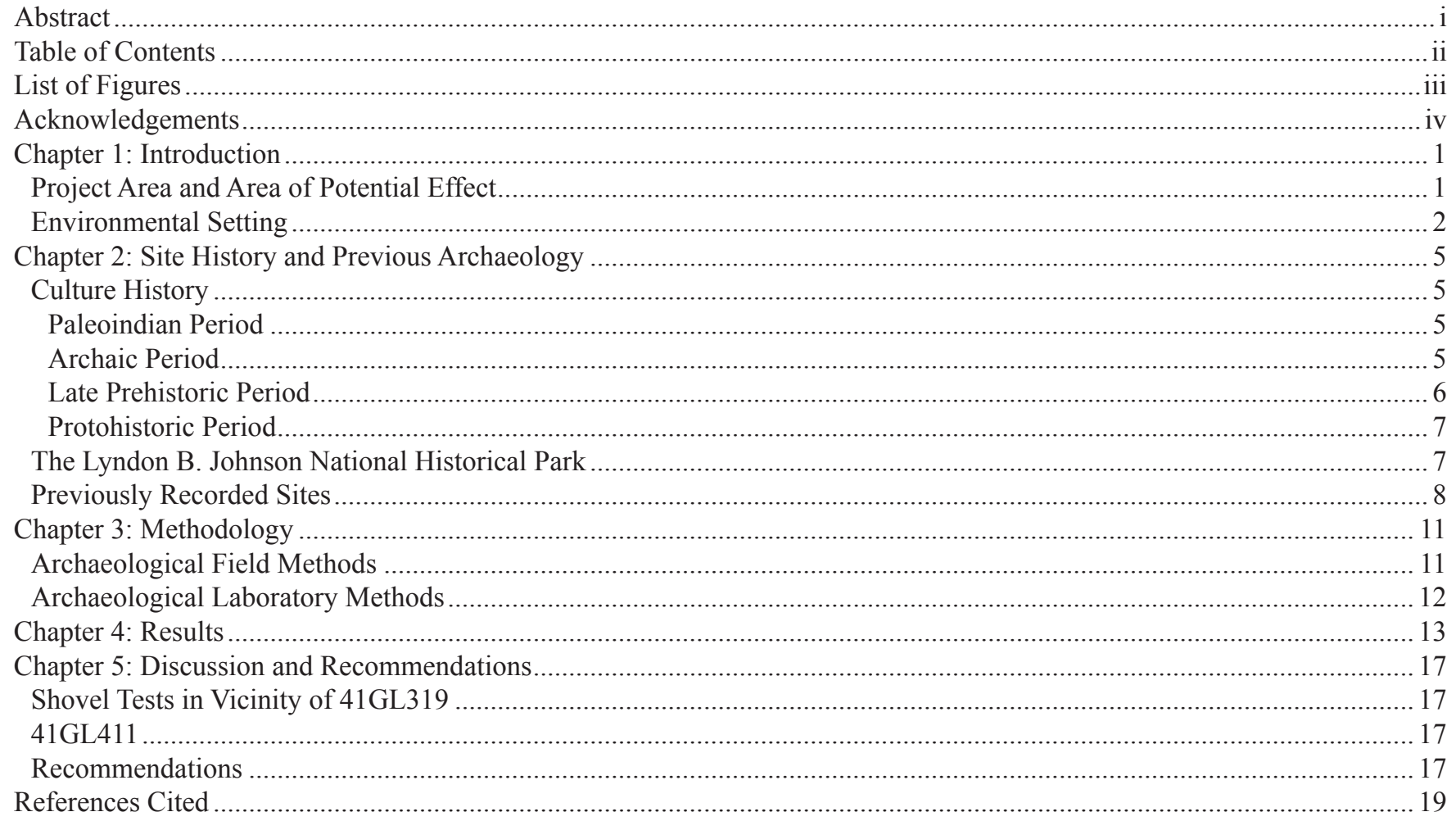




\section{List of Figures:}

Figure 1-1. Map of the project area within Lyndon B. Johnson National Historical Park. Project area is shown on the Hye, Texas (3098-214) 7.5 Minute Series Quadrangle Map.............................................................. 1

Figure 1-2. Aerial of the project area with the APE indicated in yellow. .......................................................................

Figure 1-3. Facing southwest from Davis Road showing the old river channel and Site 41GL319..................................... 3

Figure 1-4. View of Bailey Road to the north and the open fields on either side of the APE. The improvements to Bailey Road will occur along the fence line. ..................................................................................... 3

Figure 2-1. Current view (top) of the Texas White House. President Johnson's office was located in the west wing (addition on the left). Meetings were often held outside under the 400 year old oak tree (bottom)

Figure 3-1. Aerial of the project area showing the intervals in which shovel tests were to be placed................................... 11

Figure 4-1. Aerial of the project area showing the shovel tests excavated along Bailey Road and Davis Road 13

Figure 4-2. Shovel Test 30. PVC pipe encountered at $47 \mathrm{~cm}$ below surface................................................................. 14

Figure 4-3. Shovel Test 15. PVC pipe encountered at $35 \mathrm{~cm}$ below surface ................................................................. 14

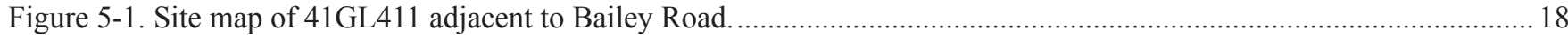




\section{Acknowledgements:}

The author would like to thank those that were involved in the successful completion of the project. The field crew consisted of Cyndi Dickey, Lindy Martinez, Bruce Moses, and Steve Smith. In addition, Bruce Moses helped to prepare the maps and figures for the report. The author would also like to thank Sherry Justus of the Lyndon B. Johnson National Historical Park for all her assistance during the project and planning stages. Special thanks to Harold Reese of the LBJ Ranch who gave the crew a tour of the facilities and offered much valuable information. Marybeth Tomka oversaw the processing of the cultural material recovered during the course of the project. Also, thanks to Dr. Steve Tomka, CAR Director, for his oversight and guidance throughout the project. 


\section{Chapter 1: Introduction}

The Center for Archaeological Research (CAR) at The University of Texas at San Antonio was contracted by the National Park Service to carry out archaeological services associated with proposed improvements to two park roads. The NPS intends to expand and relocate two roads on the LBJ Ranch in the interest of visitor safety. A portion of Bailey Road on the LBJ Ranch will be widened.

\section{Project Area and Area of Potential Effect}

Lyndon B. Johnson National Historical Park is located in the Texas Hill Country and is shown on the Hye, Texas (3098-214) USGS 7.5 Minute Series Quadrangle Map (Figure 1-1). The park can be accessed through two visitor areas located 14 miles from each other. One visitor area includes the Visitor Center, the Boyhood Home, the Johnson Settlement and the Park Headquarters. This section can be accessed from Johnson City. The second area is located near Stonewall and includes the LBJ Ranch. The entire park consists of 674.15 acres. The project area is located on the LBJ Ranch portion of the park, approximately 200 meters from the Pedernales River. The LBJ Ranch is listed on the National Register of Historic Places (NRHP). The period of significance of the NRHP listing is 1869 through 1973.

The Area of Potential Effect (APE) includes two sections near the entrance to the LBJ Ranch (Figure 1-2). One section consists of a modified new entrance from Park Road 49 onto Bailey Road. The entrance, planned to the east of the existing intersection of the two roads, will be approximately 12 feet ( 3.7 meters) wide and 367.5 feet (112 meters) in length to the point at which it meets

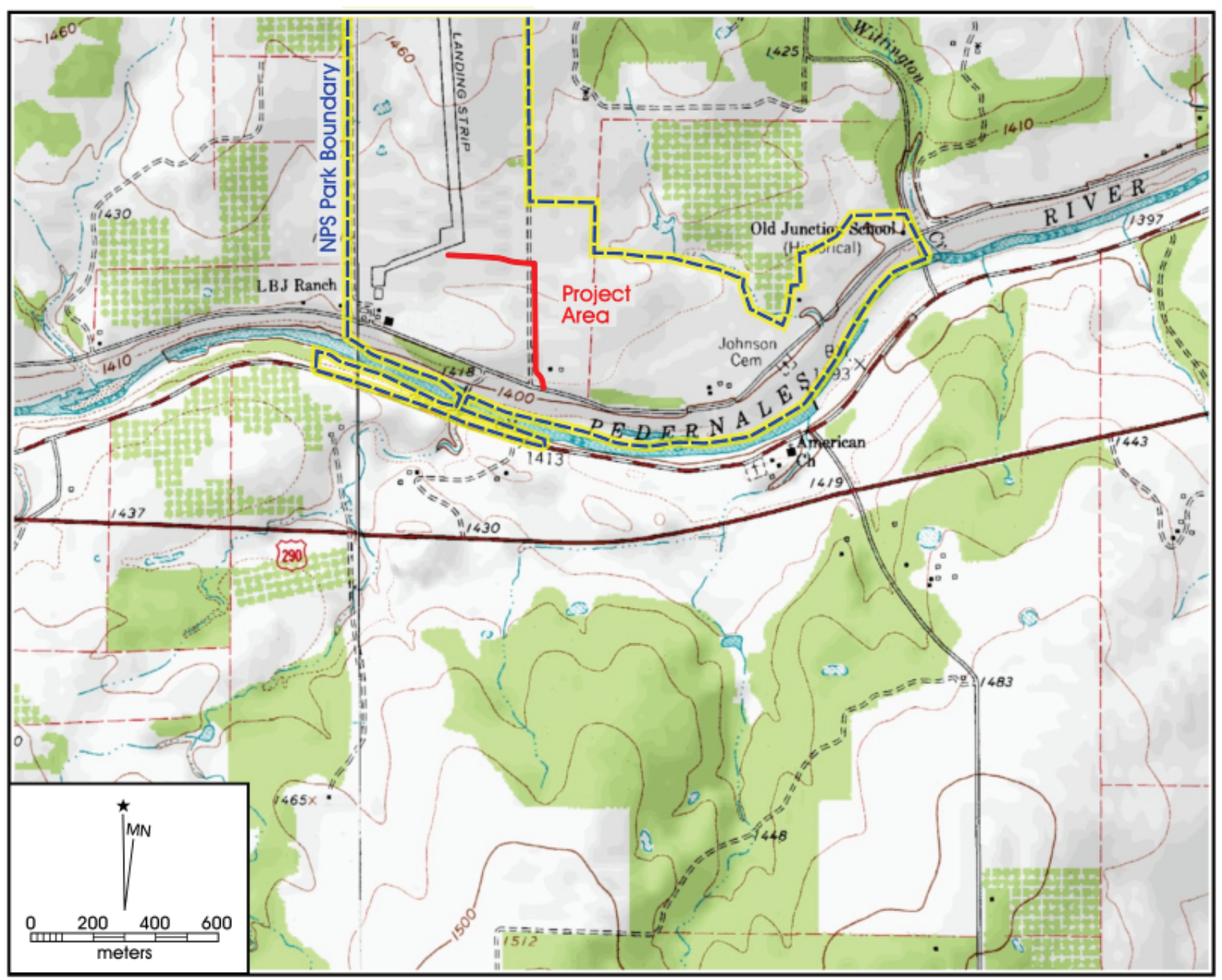

Figure 1-1. Map of the project area within Lyndon B. Johnson National Historical Park. Project area is shown on the Hye, Texas (3098-214) 7.5 Minute Series Quadrangle Map.. 


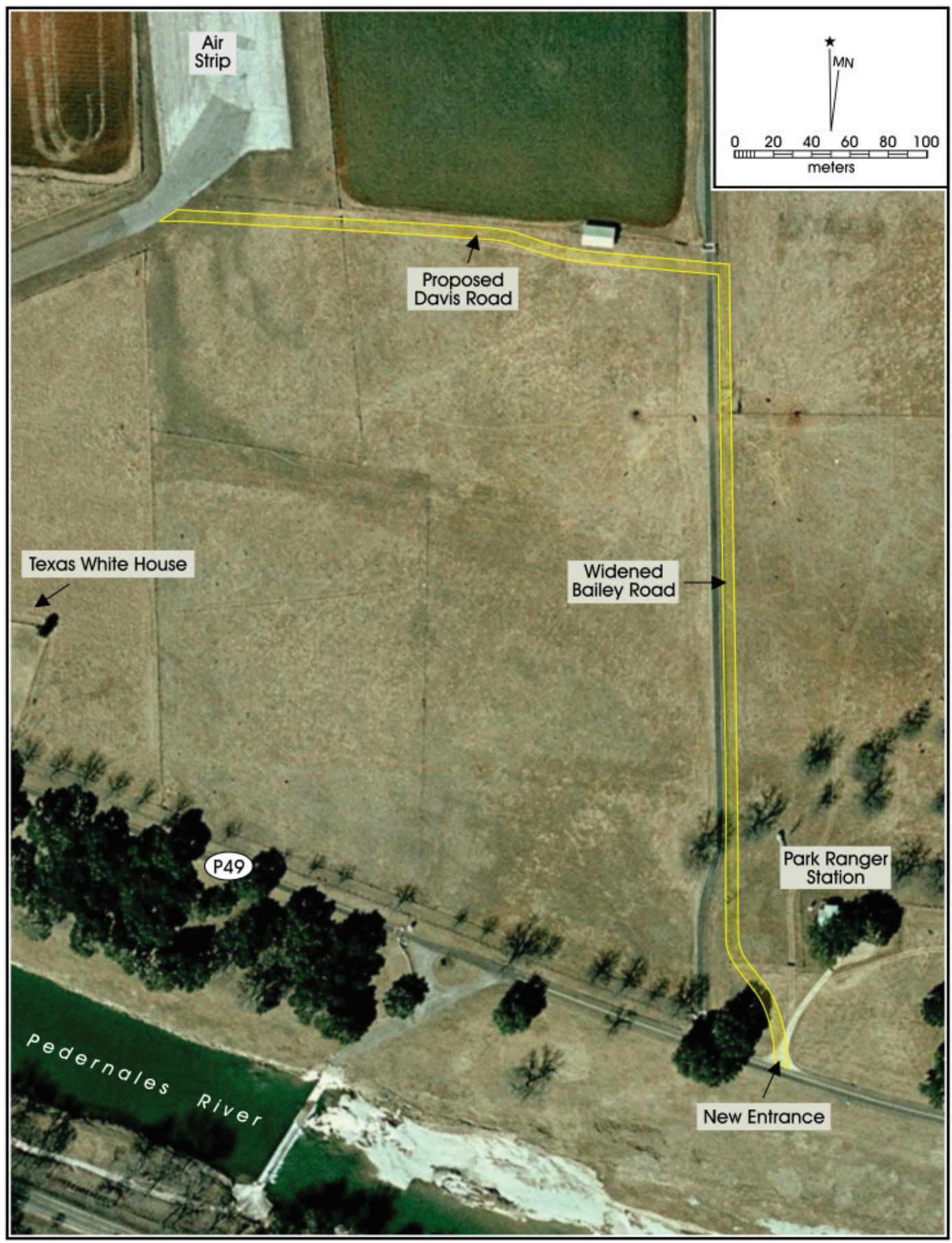

Figure 1-2. Aerial of the project area with the APE indicated in yellow.

existing Bailey Road. North of where the two roads will meet, Bailey Road will be widened a total of 12 feet (3.7 meters) to the east of the current road and for a distance of 300 meters to the north of where to old and new entrances meet. The new road to connect Bailey Road with the existing airstrip taxiway will be named Davis Road. Davis Road will be approximately 24 feet ( 7.4 meters) wide and 919 feet (280 meters) long.

\section{Environmental Setting}

The project area is located just north of the Balcones Escarpment and ecotone, on the Edwards Plateau region. "Hill Country" is the vernacular term that is used to describe the collection of 25 Texas counties that sit in a region bounded on the east and south by the Balcones Escarpment, on the west by the Edwards Plateau, and on 


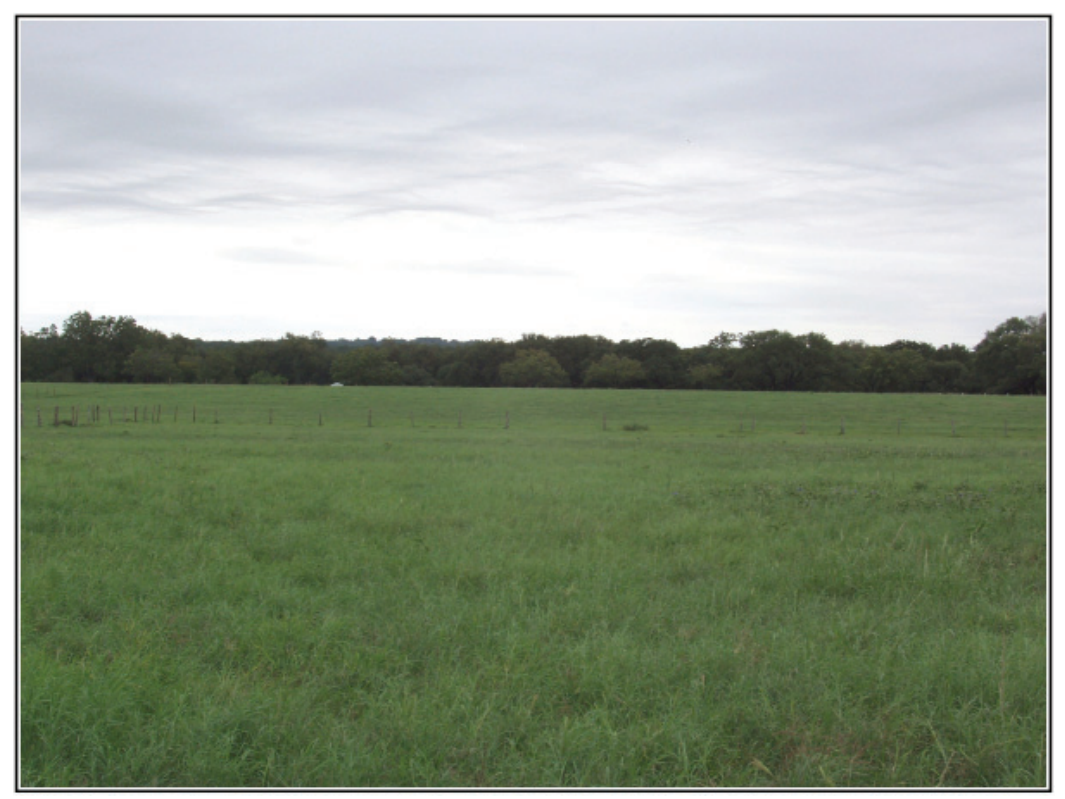

Figure 1-3. Facing southwest from Davis Road showing the old river channel and Site $41 G L 319$.

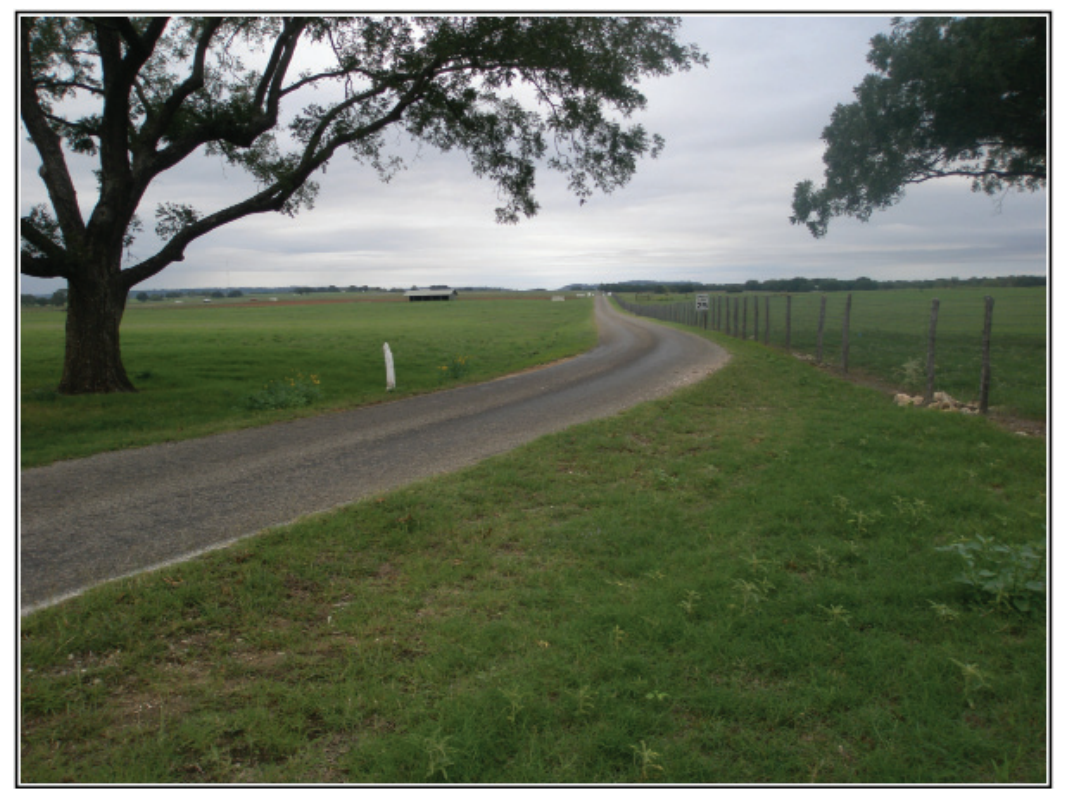

Figure 1-4. View of Bailey Road to the north and the open fields on either side of the APE. The improvements to Bailey Road will occur along the fence line. the north by rolling plains and prairie. The elevation within the region does not exceed 1,300 feet above mean sea level (amsl), with the average being less than 1,000 feet amsl. Gillespie County sits in the transition zone between humid and semi-arid climate regions.

The project area is pastureland covered in low to medium grasses. Surface visibility is low due to the vegetation cover. The APE is located just north of the Pedernales River, and is crossed by a paleo-channel in the northern portion of the project area (Figure 1-3).

The areas adjacent to Bailey Road and location of the new Davis Road are used as grazing grounds for the LBJ cattle during the wet seasons (Figure 1-4). The fields are located to the northeast of the Texas White House. Soils of the area are Bastrop fine sandy loam and Guadalupe loam, of the LuckenbachPedernales-Heatly Association \#3 (41GL319 site form). Previous excavations in the area indicate that the soils consisted of clays (LBJ Ranch Archeological Inventory 2007). 



\section{Chapter 2: Site History and Previous Archaeology}

\section{Culture History}

The culture history of south-central Texas spans nearly 11,500 years. The sequence is divided into four periods that are distinguished by changes in subsistence technologies and material culture prior to the arrival of non-indigenous people. The four periods are: Paleoindian, Archaic, Late Prehistoric, and Protohistoric. The culture chronologies of Central Texas produced by Collins (2004) and Prewitt (1981) are the standard summaries referenced by many researchers in the region.

\section{Paleoindian Period}

The earliest period recorded in the prehistory of Texas is the Paleoindian Period. This period marks the first signs of human population in the New World. The Paleoindian Period is characterized by the end of the Pleistocene and spans roughly between 11,500 and 8800 B.P. It is believed that hunter-gatherer subsistence focused on the procurement of large game (megafauna), but the archaeological material including projectile points indicate a more diverse strategy. The previous views on hunter-gatherer adaptations during this period are currently being reassessed. Though populations took advantage of the presence of the megafauna, they should more accurately be characterized as generalized huntergatherers who exploited smaller game and a variety of plants. Isolated projectile points of Paleoindian age are relatively common in the state (Largent and Waters 1999). Three sites in Texas confirm the use of the region during the Paleoindian Period. The earliest example of Paleoindian occupation is found at the Aubrey site in Denton County. Radiocarbon assays from the site place the Paleoindian occupation at around 11, $542 \pm 111$ B.P. and 11, $590 \pm 93$ B.P. (Bousman, et al. 2004:48). The faunal assemblage recovered during the excavations of the Aubrey site indicates a wide range of taxa that suggest reliance on a variety of large and small game.

The Paleoindian Period is often divided into early and late portions based on projectile point forms and gradual shifts in subsistence patterns. The early portion of the Paleoindian Period is limited to the occurrence of Clovis and Folsom fluted projectile points. These points were used in the hunting of megafauna. The later portion of the Paleoindian Period is defined based on the occurrence of Plainview, Dalton, Angostura and Scottsbluff dart points. The distribution of all Paleoindian points is relatively broad suggesting wide ranging hunter-gatherer mobility patterns.

\section{Archaic Period}

The Archaic Period spans from the end of the Paleoindian, 8800 B.P., to approximately 1200 B.P. The Archaic Period accounts for two-thirds the prehistory of central Texas (Collins 2004). The Archaic is typically divided into three sub-periods: Early, Middle, and Late. Overall, during the Archaic, hunter-gatherers appear to have shifted to the exploitation of more localized environments. The differences in Archaic sub-periods are marked by changes in climate, material culture, and site characteristics. Hunting practices focused on medium and small game, with continued efforts in gathering plant resources.

\section{Early Archaic}

The early part of the Archaic Period spans from 8800 to 6000 B.P. Three projectile point types are typical to this subperiod: Angostura, early split-stem, and Martindale-Uvalde. The climate during the early part of the Archaic appears to have been drier than during the Paleoindian Period allowing the grasslands to return (Bousman 1998). The megafauna of the Paleoindian Period could not adapt to the changes and eventually died out. With the absence of the megafauna, hunter-gatherers shifted their strategy to the exploitation of smaller game. Fishing and supplementing their diet with plant resources were additional ways that inhabitants adapted to the new subsistence challenges faced in the Archaic Period (Collins 2004).

Some authors have noted that there is a concentration of Early Archaic components along the southern and eastern Edwards Plateau (Johnson 1991; McKinney 1981). These sites have produced an array of stone tools including bola stones, net sinkers, hammer stones, Guadalupe bifaces, unifaces and other bifaces (Collins 2004). Though data is sparse for this sub-period, it appears that these tools were used in the hunting of smaller game such as deer, fishing, and processing vegetal material such as bulbs.

It is possible that the hunter-gatherers inhabiting the region during this sub-period were living along the liveoak savannah in areas where water was readily available (McKinney 1981). Such settings would have been prime locations to exploit resources such as deer, turkey, fish, reptiles, and amphibians, as well as a variety of fruits and nuts such as acorns, pecan, walnut, agarita berries, grapes, plums, persimmons, and grass seeds. 
Early Archaic human remains uncovered at a site in Kerr County indicate that the inhabitants had diets low in carbohydrates compared to Early Archaic hunter-gatherers living in the Lower Pecos region (Bement 1991). In addition, analyses on human remains collected from the Bering Sinkhole in Kerr County reveal that the natives did not rely heavily on $\mathrm{C}_{3}$ plant or animals that consume large quantities of $\mathrm{C}_{3}$ vegetation (Johnson and Goode 1994).

\section{Middle Archaic}

The middle portion of the Archaic Period spans from 6000 to 4000 B.P. (Collins 2004). Archaeological evidence indicates that there was a population increase during this time period (Prewitt 1983). The climate during the early part of the Middle Archaic was mesic. Bison appears to have played a role in the subsistence of hunter-gatherers (Collins 2004). As the period progressed, though, the climate began to become drier. The onset of the Altithermal drought also signified a decrease in reliance on bison as major food source. Instead, huntergatherers focused on exploiting riverine resources, small game, and xerophtytes, which thrived in the drier climate (Black 1989; Collins 2004; Johnson and Goode 1994). The use of burned rock middens became more prominent during the Middle Archaic as well. The middens were used to cook plant foods such as sotol that required longer cooking times. The shift in the use of middens and the exploitation of the different resources does not necessarily mean that the use of the oak-savannah flora and fauna was abandoned entirely by the end of the period. Rather, it signifies a shift in subsistence strategy that widened the resources being used (Collins 2004). Projectile points common to the sub-period include Bell, Andice, Calf Creek, Taylor, Nolan, and Travis types (Collins 2004; Johnson and Goode 1994).

\section{Late Archaic}

The Late Archaic sub-period spans from 4000 to 1200 B.P. (Collins 2004). This sub-period begins with a decrease in moisture but slowly becomes more mesic as it progresses. The Late Archaic is marked by the introduction of Bulverde, Pedernales, Kinney, Lange, Marshall, Williams, Marcos, Montell, and Castroville point forms. Projectile point sizes decreased during the sub-period as indicated by the smaller Ensor, Frio, Fairland, and Darl types. During the early part of the Late Archaic, there were fluctuations in temperature and rainfall. Populations are believed to have increased through this sub-period (Prewitt 1983). Some researchers divide the sub-period into a Late Archaic I and II (Johnson and Goode [(1994]), while others (Hester 2004) prefer to use a Transitional Archaic denomination for the later part of the sub-period denoting the shift in material culture.
Some researchers believe that the use of burned rock middens ceased at this time, but current research is challenging this notion (Black et al. 1996; Mauldin et al. 2003). Skeletal evidence from Late Archaic cemeteries in Central and South Texas suggests the region saw increasing population densities that may have prompted the establishment of territorial boundaries resulting in boundary disputes (Nickels et al. 1998). Human remains dating to this sub-period have been found near the Edward's Plateau at the Bering Sinkhole. Dental evidence shows a high rate of hypoplasia at this time (Johnson and Goode 1994; Munoz 2004). The rated of enamel hypoplasia in the Late Archaic increased in comparison to the rates in previous sub-periods, indicating increased nutritional stress (see also Munoz 2004).

\section{Late Prehistoric Period}

This period begins ca. 1200 B.P. (Collins 1995 2004) and lasts until the Protohistoric Period (ca. 700 B.P.). The term Late Prehistoric is commonly used to designate the period following the Late Archaic in Central and South Texas. A series of distinctive traits mark the shift from the Archaic to the Late Prehistoric Period including the technological shift to the bow and arrow and the introduction of pottery. The period includes two phases: the Austin and the Toyah.

At the beginning of this period environmental conditions were warm and dry. More mesic conditions appear to accelerate after 1000 B.P. (Mauldin and Nickels 2001). Subsistence practices remain relatively unchanged, especially during the Austin Phase. Projectile points associated with the Austin Phase include Edwards and Scallorn arrow points, while the Perdiz form is common during the Toyah Phase (Collins 1995). Though much of the technology and subsistence practices remain unchanged compared to the Late Archaic, researchers agree that the early portion of the Late Prehistoric was a time of population decrease (Black 1989).

Radiocarbon dates have revealed that a number of burned rock middens in Central Texas were used long after the Archaic and throughout the Late Prehistoric. Moreover, the peak of the used of burned rock middens occurred after A.D. 1 during the Late Prehistoric (Black 1989; Black et al. 1996). Radiocarbon dates from Camp Bowie middens support the hypothesis set forth by Black et al. (1996) and others (Mauldin et al. 2003) that burned rock middens are primarily a Late Prehistoric phenomena.

Beginning rather abruptly at about 650 B.P., a shift in technology is notable. This shift is characterize by the introduction of blade technology and the appearance of the first ceramics in Central Texas (bone-temper plainwares), 
as well as the use of Perdiz arrow points and alternatively beveled bifaces (Black 1989). Prewitt (1981) suggests that this technology encroached from north-central Texas. Patterson (1988), however, notes that the Perdiz point was first seen in southeast Texas by about 1350 B.P., and was introduced to the west some 600-700 years later.

Ricklis (1995) contends that ceramics became a part of the archaeological record in Central Texas beginning about A.D. 1250-1300. Early ceramics in Central Texas are associated with Toyah Phase components and are referred to as Leon Plain wares. The Leon Plain ceramic type includes undecorated, bone-tempered bowls, jars, and ollas with oxidized, burnished or floated exterior surfaces (Ricklis 1995). Although there is a typical set of attributes associated with Leon Plain, there is notable variation within the type. This variation is typically attributed to differences in manufacturing methods and cultural affiliations (Black 1986; Johnson 1994; Kalter et al. 2005). Stable carbon and nitrogen isotope data suggests that vessels were utilized in the processing of bison bone grease/ fat, mesquite bean/bison bone grease and deer/bison bone grease (Quigg et al. 1993).

Huebner (1991) suggests that the sudden return of bison to South and Central Texas during the Late Prehistoric resulted from xeric climate in the plains north of Texas and increased grass production in the Cross-Timbers and Post Oak Savannah in north-central Texas. Together these formed a "bison corridor" into the Southern Plains along the eastern edge of the Edwards Plateau (Huebner 1991). Settlement shifts into rock shelters such as Scorpion Cave in Medina County (Highley et al. 1978) and Classen Rockshelter in northern Bexar County (Fox and Fox 1967) have been noted during this time. Cemeteries from this period often reveal evidence of inter-group conflict (Black 1989).

\section{Protohistoric Period}

Protohistoric is a term typically used to describe the transition from the Late Prehistoric to the Historic Period and the systematic presence of non-Native American populations in the region in south and central Texas. As with the other periods, the beginning and end points of the Protohistoric Period are subjectively defined. Cabeza de Vaca's shipwreck on the coast of Texas in 1528 may be considered as the beginning period. The end of the period may be marked by Governor Alonso de Léon's expedition into Texas (Foster $1995)$ in 1689. Encounters that remained sporadic between the indigenous populations and the Europeans until the late 1600 's became more common and systematic thereafter. The increased contacts brought with them a combination of epidemic disease and gradual changes in the material culture and practices of Native Americans in Texas. Indentifying occupations dating to this period is problematic. Protohistoric sites may have a mixture of Late Prehistoric and Historic artifacts but it is difficult to define whether their co-mingling represents contemporary occupation or post-depositional mixing of materials.

\section{The Lyndon B. Johnson National Historical Park}

Lyndon B. Johnson National Historical Site was created on December 2, 1969 (Long 1996). The park features his birthplace, boyhood home, his ranch, the Texas White House, the old Junction School (Johnson's childhood school), and the Johnson Family Cemetery. The birthplace home was built in the 1880s by Samuel Ealy Johnson, Sr. In 1907, Samuel Ealy Johnson, Jr. brought his bride to live at this home. Lyndon Johnson was born in this house on August 27, 1908. The Johnsons resided at this house until 1913, at which time they moved to Johnson City. The original structure was demolished during the 1930s, but a smaller building was built in the same spot, utilizing some of the same materials (Tyler 1996). It was reconstructed primarily to the specifications of the earlier structure (Tyler 1996). President Johnson was very active in the reconstruction of the home, hiring architect Roy White of Austin and supplying photographs of the original structure. President Johnson and Roy White consulted family members to gather information that was valuable in the reconstruction efforts. The house later became a museum displaying family furnishings and memorabilia. This structure is the only birthplace of a President that was reconstructed, refurbished and interpreted by an incumbent President (NPS 2009).

The home that the Johnsons moved to in 1913 was constructed in 1901. Lyndon Johnson used this house as his primary residence until he married Claudia Alta Taylor (Lady Bird) in 1934. This house was also converted into a museum in 1965. The museum displayed period pieces and family artifacts.

The LBJ Ranch is located along the Pedernales River. The tract of land was originally granted to Rachael Means during the Texas Republic Period. Later the property was conveyed to the next landholder in 1872. Archival research indicates that a one-room log cabin was built on the property prior to 1894. Between 1894 and 1895, a two story stone house was constructed on the property by the Meier family (NRHP 1990). The Meier Family conveyed the property in 1906 to Charles Wagner, Jr. In the same year, Wagner sold the property and 350 acres to James G. Odiorne. The property was obtained by Clarence White Martin on June 22, 1909. Martin was a relative of the Johnsons. The Martins lived in the residence for 42 years before they sold it to Lyndon B. Johnson. 
The Martins were responsible for several improvements to the original stone structure. In 1912, Clarence Martin had several rooms added to the structure. Also, Martin had the elevated fireplace constructed in an old portion of the house at this time (NRHP 1990). The Johnsons acquired the property in 1951 from his Aunt Frank Martin. At this time, Lyndon B. Johnson was a Senator (Tyler 1996). Part of the purchase of this house involved the trading of the Johnson City home. The Johnson City house was repurchased after Aunt Frank's death.

Upon purchasing the Martin property, Johnson set about making some changes to the structure as well. A swimming pool and cabana were added. In 1983, Mrs. Johnson had an enclosed heated pool constructed that was attached to the east end of the cabana. The pool was heated through solar energy. In the 1960s, a steel framed carport with corrugated metal roof was constructed to house Johnson's collection of cars. Also constructed in the 1960s was the steel framed hanger located to the west of the main house. The hanger served several purposes over the years. Not only was it used to house aircraft, but also used for viewing motion pictures, parties, and press conferences after Lyndon B. Johnson became President (NRHP 1990). Currently, though the exterior of the structure remains similar to the time of the Presidency, the interior of the structure has been modified as a Visitor Contact Area, Gift Shop, and houses five of LBJ's vehicles for display.

When Johnson became President of the United States of America, just hours after the assassination of President J.F. Kennedy, certain changes were made at the LBJ Ranch. First, a new wing was added to the house. This western wing became President Johnson's office during his stays at the ranch. Johnson spent a significant time of the presidency at his ranch home (Figure 2-1). His office was too small to accommodate group meetings, so they would often assemble outside under the 400 year old oak tree around a patio table to discuss pressing political issues. Due to the exterior color of the home, and the fact that Johnson performed his duties from the location, the main house came to be referred to as the Texas White House.

Just behind the White House, a six room building was constructed to house the Secret Service who were to protect the President and First Lady. At least two guards were stationed on duty at all times. After President Johnson's death, the Secret Service continued to use the structure as their headquarters and housing while providing protection for Mrs. Johnson. The airstrip located to the north of the White House was constructed prior to Johnson becoming President. After he took office, though, the strip was elongated to accommodate additional traffic.
The LBJ Ranch was listed on the National Register of Historic Places on December 2, 1969. The period of significance for the Lyndon B. Johnson National Historical Park is 18691973. The site includes all structures that were directly associated with President Johnson, or met NRHP Criterion A (associated with significant events of our history) and B (associated with lives of persons significant to our past). In addition, the Lyndon B. Johnson National Historical Park was nominated as an NRHP District in 1990 at the national level of significance.

President and Mrs. Johnson donated the Texas White house in December 1972 and established a life estate for themselves at that time. At the time of both of their deaths, the structure was to become part of the National Park. President Johnson passed away in 1973. Lady Bird Johnson lived for many years after at the White House. She passed away in 2007. Just recently, renovations were begun to return it to its appearance during Johnson's Presidency. The President's office was restored to resemble its appearance during Johnson's term. The living room, with the elevated fireplace, as well as the dining room and kitchen were restored using the Johnson's family furniture. Future plans include opening the entire downstairs of the house.

Several of the structures on the park property have been reconstructed, but were considered significant because they provided visual contributions to the history of the site. President Johnson participated in the reconstruction of several of the structures.

\section{Previously Recorded Sites}

One previously recorded site is located within the immediate vicinity of the project area. Site 41GL319 is a prehistoric site that consisted of a sub-surface lithic scatter. The site was recorded during the Lyndon B. Johnson NHP Archeological Inventory Shovel Test Survey conducted by NPS in 2005. The southern portion of the site is located off Park Road 49. The site is west of and abuts Bailey Road. Shovel testing produced cultural materials through Level $7(60-70 \mathrm{~cm}$ below surface $[\mathrm{cmbs}])$. The majority of the material encountered consisted of debitage, as well as one biface and two fragments of fire-cracked rock. One untyped chert projectile point stem fragment was recovered during the shovel testing. At the time of the survey, it was suggested that the site has potential for producing significant intact cultural deposits as the majority of the site appears to be relatively undisturbed. The site is extensive ( 2.6 hectares), although the deposits are relatively shallow. The majority (96\%) of the artifacts encountered were found within the first four levels of the shovel tests (0$40 \mathrm{cmbs}$ ). Two concentrations of material make up the site. 

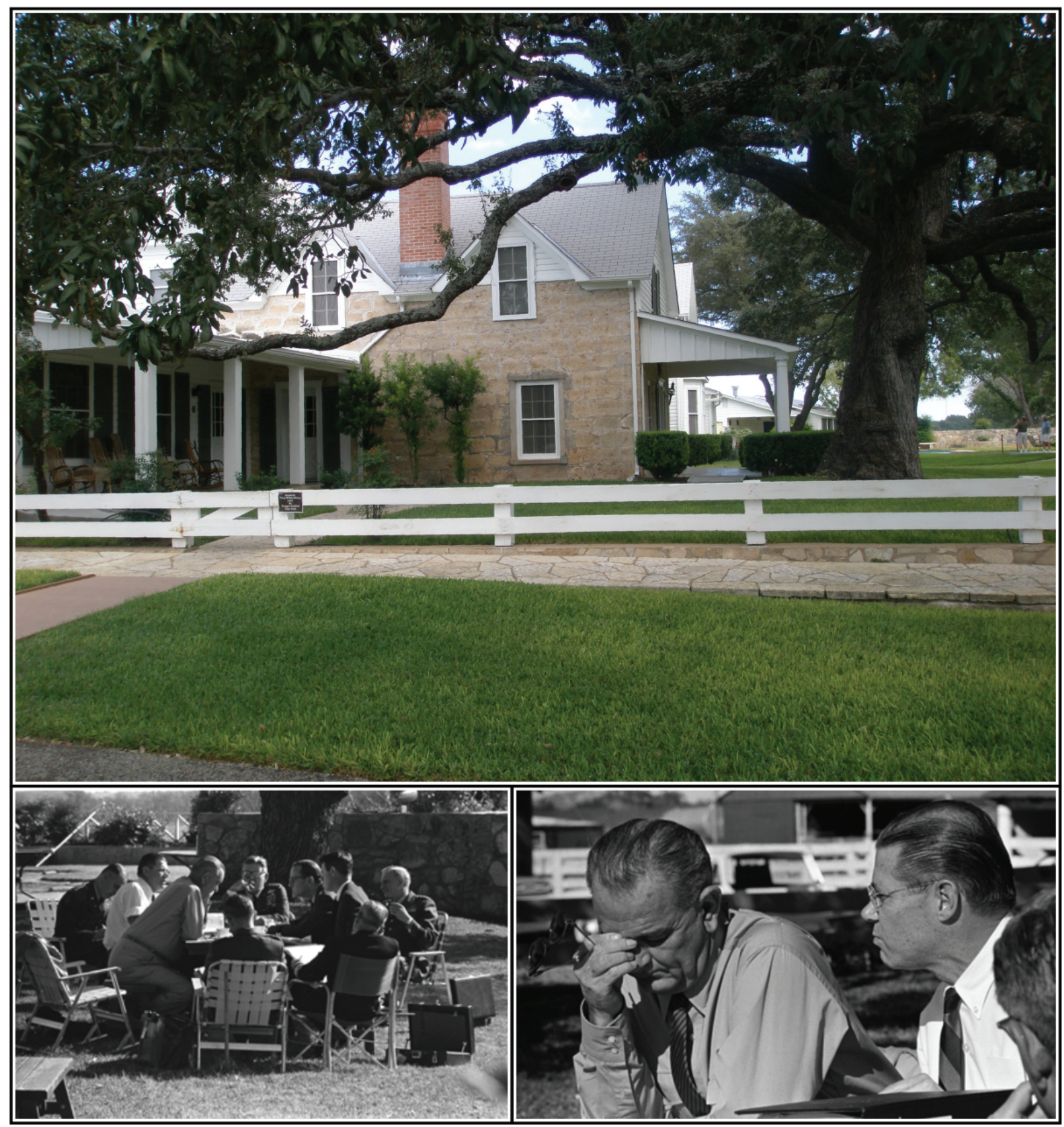

Figure 2-1. Current view (top) of the Texas White House. President Johnson's office was located in the west wing (addition on the left). Meetings were often held outside under the 400 year old oak tree (bottom).

One concentration appears to be located near the center while the other is in the western portion of the site. The western portion of the site was not investigated fully during the original survey (41GL319 Site Form). The site may extend to the Texas White House. The edge of the concentration of artifacts closest to Bailey Road is approximately 75 to 110 meters to the west of the road. The original boundary of the site was recorded as not extending to Bailey Road. To shovel tests located 20 meters to the west of Bailey Road produced debitage, though the shovel tests were located approximately 50 meters from each other and at least 60 meters from the nearest artifact concentration. When the site was recorded 
on the Texas Sites Atlas, the site boundary was extended to include these two positive shovel tests. The site was thought to be potentially eligible for listing on the National Register of Historic Places (NRHP).

Additional sites that are located within a half-mile radius of 41GL319 include: 41GL4, 41GL5, 41GL7, 41GL10 and 41GL136. Sites 41GL4, 41GL5, 41GL7 and 41GL10 are located south of the Pedernales River. Two of these sites are historic structures (41GL 4 and 41GL5) and the other two are prehistoric sites. 41GL4 is known as the Sweeney Place, a 1800 s dog-trot $\log$ cabin with a stone foundation. Also located within the site boundaries were two stone milk cellars and a trash dump. The site was excavated in 1968.

Site 41GL5 is known as the Hightower Place. This property exhibits three stone buildings that were built between 1850 and the 1930s. Associated with the structures were several cellars. The site occupies approximately $100 \mathrm{~m}^{2}$. The Hightower Place was recorded in 1968.

41GL7 was recorded in 1968 as a prehistoric site. Excavations at the site revealed hearth features as well as evidence of lithic tool production. The site is approximately $25 \times 10$ meters and relatively shallow with the cultural material recovered in the upper $15 \mathrm{~cm}$ of excavation. The soils encountered at 41GL7 were black loam and brown sandy clay.

Site $41 \mathrm{GL} 10$ is the prehistoric component in the vicinity of the Sauer Place. The type of prehistoric site was not recorded on the site form. The soils of the area are rocky and consist of a mix of caliche, red clay, and loams.

Site 41GL136 is located to the northwest of the project area. This site was recorded as the LBJ Ranch, though the boundary does not seem to include the entirety of the property. The Texas White House, the main house, is situated within the site boundaries. The site is recorded as Lyndon B. Johnson's ranch and homestead.

Additional sites are located to the east of the project area, although beyond the half-mile radius. These sites appear to be linked to the use of the property by Lyndon B. Johnson and his family. Those sites are included in the Lyndon B. Johnson National Historical Park and the Lyndon B. Johnson State Park and Historical Site. 


\section{Chapter 3: Methodology}

\section{Archaeological Field Methods}

According to the schematics of the planned road improvements provided to CAR, the expansion along Bailey Road will involve its widening by approximately 3.7 meters on the east-side of the current road, and the construction of a new segment to connect to Park Road (PR) 49. In addition, the road improvements will also result in the installation of Davis Road to the north of PR 49 connecting Bailey Road to the existing air strip.

To determine whether these proposed improvements would impact any cultural deposits, the CAR proposed to conduct a linear archaeological survey of the APE, the areas to be affected by the widening of Bailey Road and the construction of Davis Road within the LBJ Ranch National Historical Park (Figure 3-1). The CAR staff consulted with the staff of the Texas Historical Commission to determine a Scope of Work and levels of effort in different portions of the project area. Different levels of shovel testing were necessary due to varying distances of the project area from the boundaries of 41GL319, the previously defined site.

Based on the different levels of effort projected along the APE, the project area was divided into four segments. The portion of Bailey Road that was to be impacted by its widening and the construction of the new intersection with PR 49 consists of 412 meters. The route was marked by NPS staff prior to the archaeologists' arrival to the APE. CAR shovel tested the previously un-investigated 112-meter section of the new be placed. route of Bailey Road (Section 1) at 30-meter intervals. Four shovel tests were excavated along this segment (Figure 3-1). In addition, CAR excavated one shovel test for every 10 meters in the portion of Bailey Road that abuts site 41 GL319 (Section 2). A total of eight shovel tests were excavated in this 80 meter section. The remainder of Bailey Road (approximately 220 meters; Section 3) was surveyed

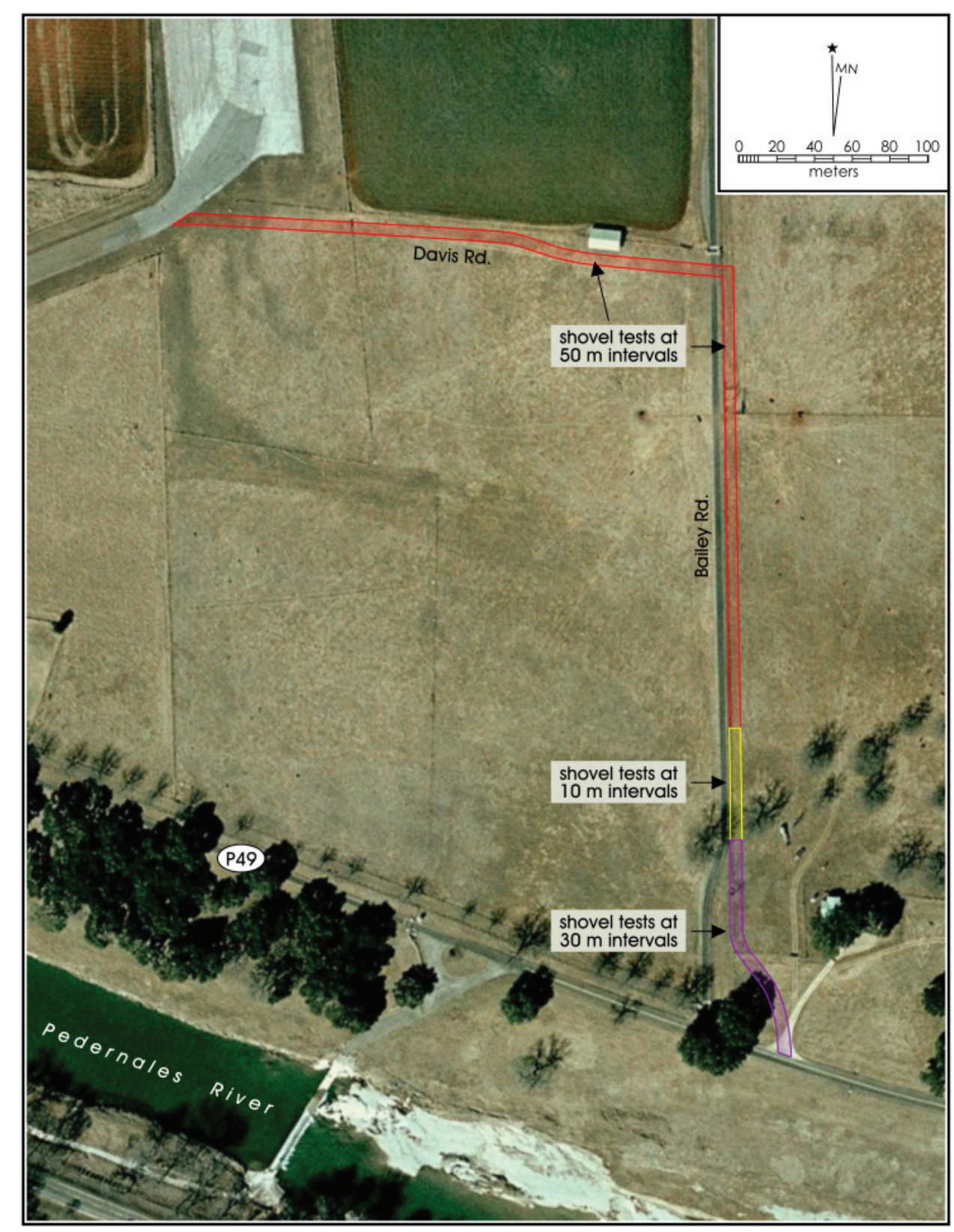

Figure 3-1. Aerial of the project area showing the intervals in which shovel tests were to 
using shovel tests excavated at 50 meter intervals exceeding THC minimum survey standards. A total of nine shovel tests were excavated.

Davis Road (Section 4) will head west from Bailey Road and connect to the air strip located in the northwest portion of the project area (Figure 3-1). Davis Road will be approximately 280 meters in length and approximately 7.3 meters wide (Figure 3-1). Exceeding the THC minimum survey standards, eight shovel tests were excavated, at a rate of one for every 50 meters surveyed, along this proposed road (Section 4).

Shovel tests were $30 \mathrm{~cm}$ in diameter, and unless prevented by obstacles, extended to a depth of $60 \mathrm{~cm}$ along the route of the linear survey. Shovel tests were excavated in 10-cm increments, and all soil from each level was screened through 1/4-inch hardware cloth. All artifacts recovered were recorded with appropriate provenience information for laboratory processing, analysis, and temporary curation. A shovel test form was completed for every excavated unit. Data collected from each shovel test included the final excavation depth, a tally of all materials recovered from each 10-cm level, and a brief soil description (texture, consistence, Munsell color, inclusions). A profile sketch was included on the shovel test form, if warranted. The location of every shovel test was recorded with Trimble Geo XT GPS units. Shovel test locations also were sketched onto topographic maps or aerial photographs as a backup to GPS information. Any additional observations considered pertinent were included as comments on the standard shovel test excavation form.
When a positive shovel test was encountered, additional units were excavated at 10 meter intervals along the route of the survey until a test produced no cultural material. The APE was marked with blue pin flags prior to the archaeologists' arrival at the project area.

\section{Archaeological Laboratory Methods}

Cultural materials and records obtained and/or generated during the project were prepared for curation in accordance with federal regulation $36 \mathrm{CFR}$ part 79, and THC requirements for State Held-in-Trust collections. Additionally, the materials were processed in accordance with current guidelines of the CAR. Artifacts processed in the CAR laboratory were washed, air-dried, and stored in 4-mm zip locking archivalquality bags. Materials needing extra support were doublebagged. Acid-free labels were placed in all artifact bags. Each label contained provenience information and a corresponding lot number written in archival ink, with pencil or laser printed. The unmodified debitage from each lot was labeled with the appropriate provenience data. Artifacts were separated by class and stored in acid-free boxes. Digital photographs were printed on acid-free paper, labeled with archivally appropriate materials, and placed in archival-quality sleeves. All field forms were completed with pencil. All artifacts and documentation pertaining to the project were temporarily curated at the CAR facility. The permanent curation facility for housing the collections is the LBJ National Historical Park HQ Building Curatorial Storage. 


\section{Chapter 4: Results}

During the course of the one-day pedestrian survey of the APE, thirty shovel tests (STs) were excavated. These shovel tests were placed within the APE that was delineated by pin flags prior to the archaeologists' arrival (Figure 4-1).

The first segment investigated was the new portion of Bailey Road that begins at the service path off Park Road 49 and connects to the original Bailey Road approximately 112 meters (367.5 feet) to the northwest. Four shovel tests were excavated within this segment, STs 1 through 4 (Figure 4-1). All four shovel tests were negative. Two distinct soils were encountered within this segment. The soil in STs 1 and 2 located nearest to PR 49 consisted of reddish sandy clay. The soil was fairly easy to excavate and remained consistent in color and texture from the top to the terminal depth of the units. STs 3 and 4 encountered a reddish silty sand with very low clay content.

The second segment was located just west of the western boundary of Site 41GL319 (Figure 4-1). Nine shovel tests excavated in this section of the APE: STs 5, 18, 19, 23-25, 2830. Of these, two (STs 18 and $28 ; 22 \%$ ) were positive. ST 18 , located in the northern portion of this segment, produced a metal fencing staple in the upper 10 $\mathrm{cm}$ below surface. The fencing staple is typical of the type used on any farm or ranch, though it does not match the fasteners used on the current fence. The staple is highly rusted. No other cultural material was recovered during the excavation of ST 18. ST 19 was excavated 10 meters and Davis Road. to the north of ST 18. It was negative as was ST 23 located 10 -meters to the south of ST 18.

The second positive shovel test was ST 28. This test produced a piece of lithic debitage (flake) in Level 5 (40$50 \mathrm{cmbs}$ ). No other cultural material was encountered in this shovel test. STs 25 and 29 were excavated to the north

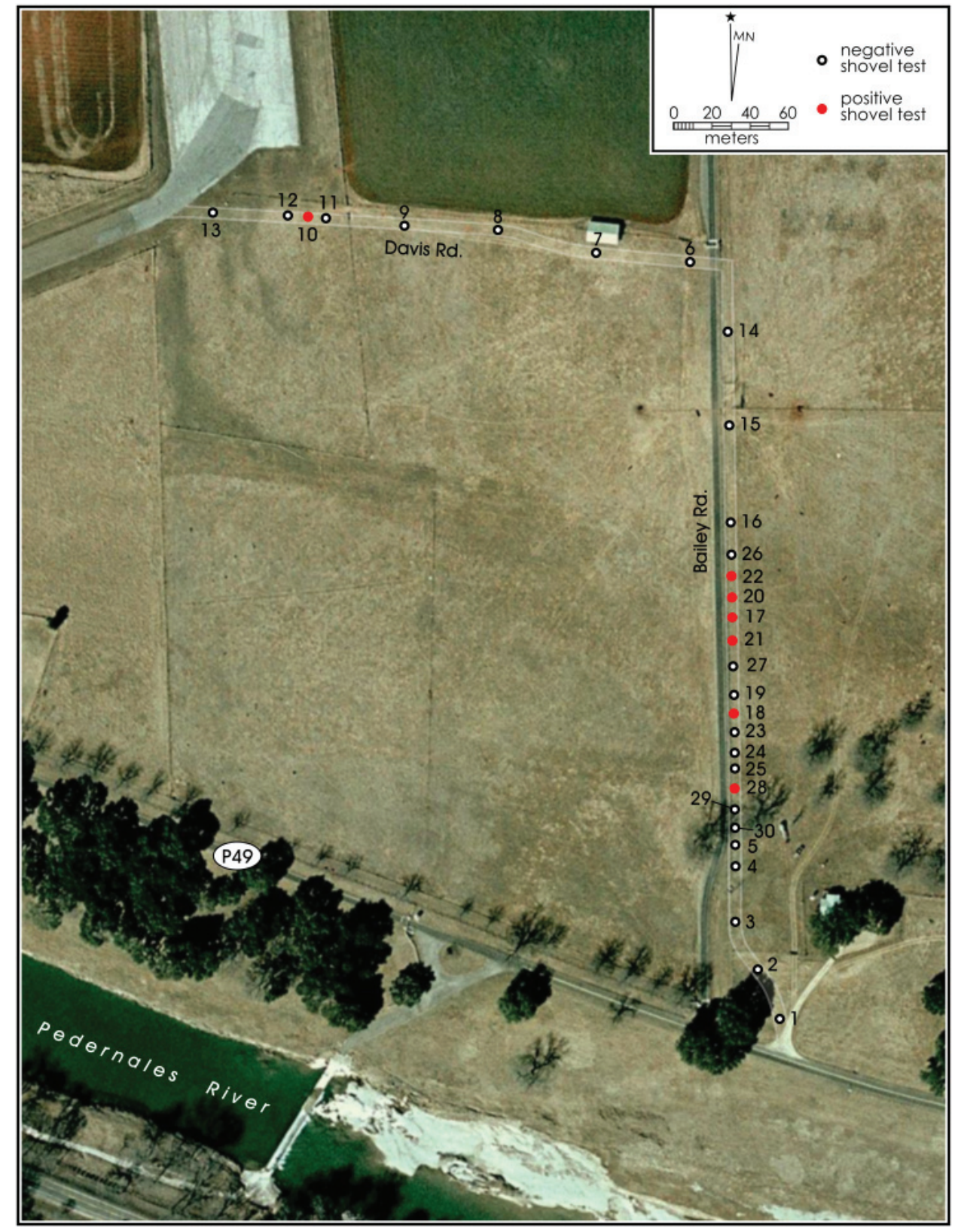

Figure 4-1. Aerial of the project area showing the shovel tests excavated along Bailey Road 
and south, respectively, at 10 meters from ST 28. Both shovel tests produced no cultural material.

Seven of the units, STs 18, 19, 23, 24, 25, 28, and 29, produced similar soils. The upper levels encountered slightly reddish brown sandy clay that appeared to contain a high percentage of sand. The clay content of the soil increased with depth as did its reddish color. A few gravels were encountered usually in Level 6 (50-60 cmbs) of the shovel tests.

ST 30 consisted of pure sand. The sand was reddish brown in color and very fine in texture. At $47 \mathrm{~cm}$ below the surface, a black PVC pipe was encountered in the western portion of the unit (Figure 4-2). The pipe was accidently broken during the excavation of the unit. Upon notifying the NPS personnel, it was decided that the pipe was either part of an old irrigation line, or belonged to the livestock trough system. The shovel test excavation was terminated at this depth and the unit was not backfilled to allow pipe monitoring by NPS staff. Similar reddish fine sand also was encountered in ST 5. This shovel test was excavated to $60 \mathrm{cmbs}$, and did not encounter a pipe. No evidence of disturbance was noted during the excavation of the unit.

Section 3 of the project area consisted of the remainder of Bailey Road north of 41GL319 and to its intersection with Davis Road (Figure 3-1). Nine shovel tests (STs 1417, 20-22, 26 and 27) were excavated in this section. The four northern most units (STs 14-16, and 26) were negative. STs 14 and 16 encountered compacted soils that consisted

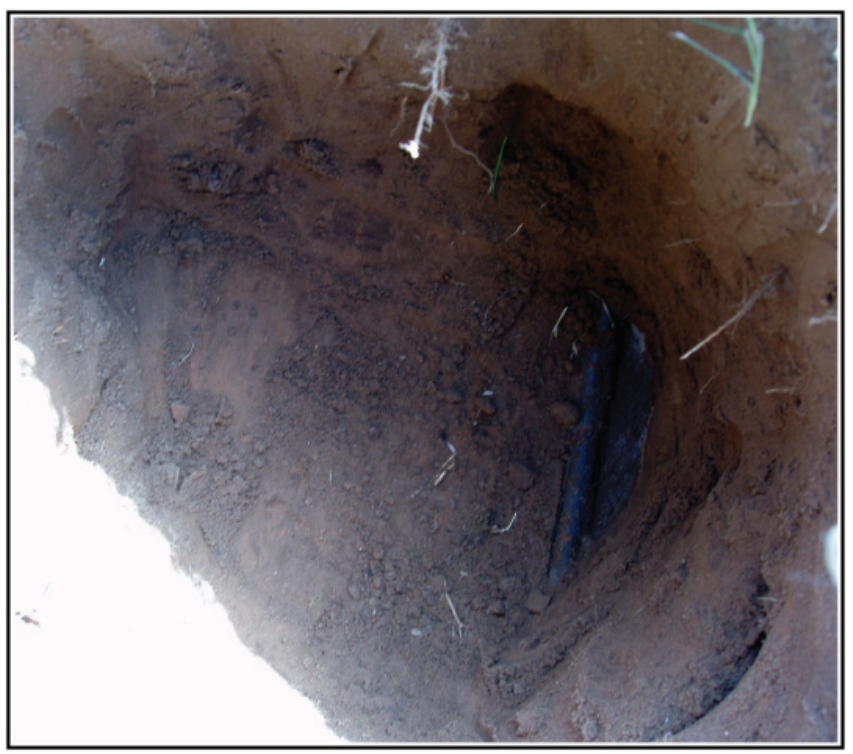

Figure 4-2. Shovel Test 30. PVC pipe encountered at $47 \mathrm{~cm}$ below surface. of reddish brown silty clay. Small carbonate nodules were present, but in low density. ST 15 was excavated near the conjunction of two fences and a gravel road (Figure 4-1). The shovel test contained caliche fill. At $35 \mathrm{~cm}$ below surface, a black PVC pipe was encountered (Figure 4-3). The excavation of the shovel test was terminated at this point due to the disturbance.

ST 17 produced highly rusted metal fragments in Level 4 (30$40 \mathrm{cmbs}$ ). One fragment appears to have a fastener attached to it. In addition to encountering the metal fragments, excavation revealed that slag was present between 10 and $40 \mathrm{cmbs}$. Because ST 17 was positive for cultural material, additional shovel tests (STs 20 and 21) were excavated to the north and south at 10 meter intervals. Both units (STs 20 and 21) were positive for cultural material. ST 20 encountered more slag in the first $30 \mathrm{~cm}$ below surface. ST 21, excavated to the south of ST 17, produced one piece of lithic debitage. The flake was recovered in Level 2 (10-20 cmbs). Slag, distributed between 10 and $40 \mathrm{cmbs}$, was abundant. Carbonate nodules also were noted in the first level $(0-10 \mathrm{cmbs})$.

Because STs 20 and 21 were positive, additional units (STs 22 and 27) were excavated north and south of these two STs (Figure 4-1) at 10 meter intervals. ST 27 was placed approximately $10 \mathrm{~m}$ to the south of ST 21 . This shovel test encountered mottled sandy clay with carbonate nodules. The test was excavated to $60 \mathrm{cmbs}$ and encountered no cultural materials.

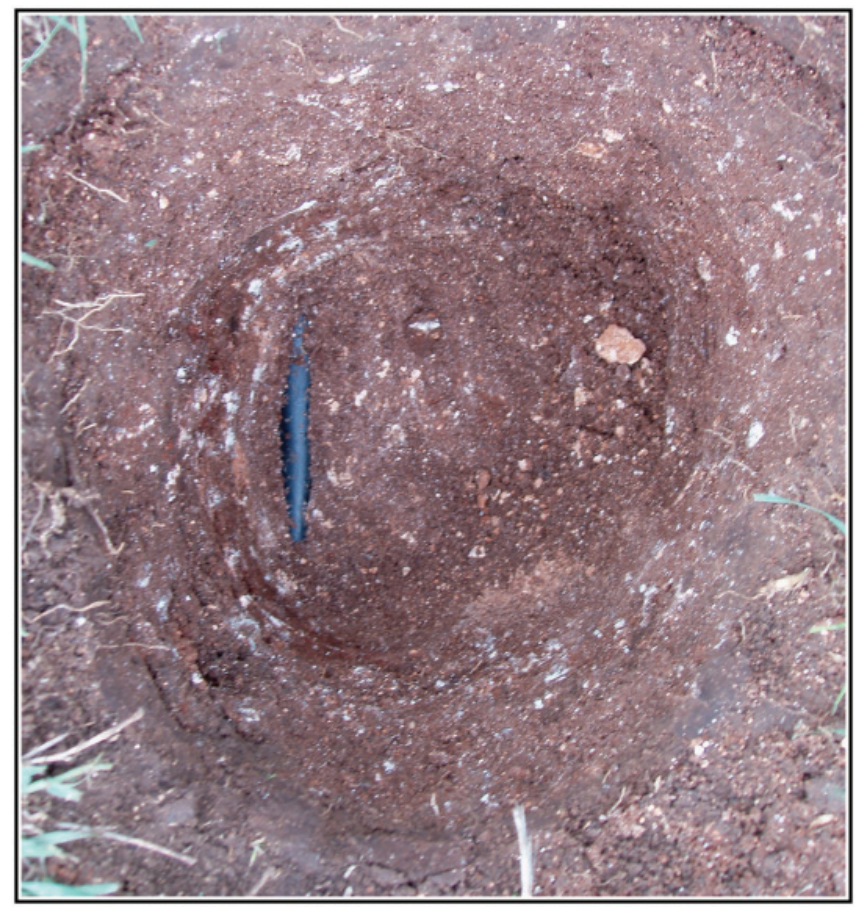

Figure 4-3. Shovel Test 15. PVC pipe encountered at $35 \mathrm{~cm}$ below surface. 
ST 22 was excavated to the north of ST 20 . This shovel test encountered slag in the first three levels $(0-30 \mathrm{cmbs})$. In Level 2 (10-20 cmbs), rusted metal fragments were encountered. In Level 4 (40-50 cmbs), one piece of lithic debitage was found. The soil consisted of compacted sandy clay similar to the matrix noted in units to the south of ST 22. An additional shovel test was excavated to the north of ST 22. ST 26 encountered the same reddish sandy clay that was found in the shovel tests located to the south. No cultural material was recovered from this shovel test.

The fourth and last segment of the linear pedestrian survey was along the route of Davis Road. While six shovel tests were planned along this segment, eight were excavated (STs 6-13). The two additional units were warranted by the fact that ST 10 produced one flake in Level $1(0-10 \mathrm{cmbs})$. The remainder of the shovel test produced no cultural material. Two additional shovel tests were excavated
10 meters to the east and west of ST 10 (STs 11 and 12, respectively). Both of these shovel tests were negative for cultural material.

There was a slight difference in the soil encountered along this section of the survey. The route of Davis Road passes through the northern portion of a field that is used for cattle grazing during the wetter months. The soil appears to be consistently dark, reddish brown sandy clay. The lower 10-20 cm of each shovel test encountered a drier version of the soil. It appears that the recent rains had softened the upper layers, while the last $10-20 \mathrm{~cm}$ of these shovel tests were difficult to dig.

In summary, thirty shovel tests were excavated along the projected route of Davis Road and the improvements to Bailey Road. Of these thirty shovel tests, seven were positive for cultural material. The material encountered consisted of metal fragments, slag, and lithic debitage. 



\section{Chapter 5: Discussion and Recommendations}

Seven of the thirty shovel tests excavated over the course of the project produced cultural materials. Each shovel test was excavated to a depth of $60 \mathrm{~cm}$ below surface unless prevented by an obstacle. The shovel testing occurred within the route of Davis Road, the improvements to Bailey Road, and the new segment of Bailey Road. Shovel test densities were calculated prior to the fieldwork to sufficiently sample the areas in relation to their locations (see below). The CAR staff conducted a linear pedestrian survey along the APE with shovel testing that exceeded the THC minimum standards. Shovel tests were place at 50 meter intervals along the route of Davis Road. A total of eight shovel tests were excavated along this path. Seven of the eight shovel tests produced no cultural material. ST 10 produced one lithic flake, which warranted the excavation of two more shovel tests located at 10 meters east and west from ST 10. These shovel tests did not produce and cultural material. The flake recovered from ST 10 has been identified as Isolated Find 1 (IF 1) since no other cultural material was recovered in the area.

The area of the proposed improvements to Bailey Road, not in the vicinity of Site 41GL319, had shovel tests also placed at 50 meter intervals. Initially, four shovel tests were to be placed in this area. ST 15 encountered a black PVC pipe that is believe to be part of an old irrigation line, or part of the cattle trough watering system. The soils in the test appeared to be caliche fill indicating that the area was disturbed. The remainder of the linear survey occurred along the new route of Bailey Road. Shovel tests were placed at 50 meter intervals. Three shovel tests were excavated and all three produced no cultural material.

The remainder of the shovel tests was excavated in the vicinity of 41GL319 and in an area designated as new archaeological Site 41 GL411.

\section{Shovel Tests in Vicinity of 41GL319}

The section of the survey that was in the vicinity of Site $41 \mathrm{GL} 319$ had shovel tests placed at 10 meter intervals. Ten shovel tests were excavated in this area. Of the ten, two produced cultural material. One fencing staple was recovered in the first level of ST 18. The shovel tests located to the north and south, ST 19 and 23, produce no additional cultural material. Therefore, the fencing staple has been identified as IF 2 .
ST 28 produced one lithic flake. The flake was recovered at $40-50 \mathrm{~cm}$ below surface. The shovel tests located to the north and the south (STs 25 and 29) produced no additional cultural material. Unlike the previously discussed isolated finds, this flake was found within the boundary of 41GL319. This flake is not an isolated find, but rather an artifact associated with the previously recorded site.

ST 30 encountered sand during the excavation. At $47 \mathrm{~cm}$ below surface a black PVC pipe was encountered. This pipe was very similar to that encountered in ST 15. It is likely that these represent the same line. This would suggest that the installation of the line would have disturbed the area in between the two shovel tests. The width of the PVC pipe trench is unknown. However, with the possible exception of ST 5, the remaining shovel tests excavated between STs 15 and 30 did not encounter the trench.

\section{GL411}

ST 17 produced cultural material in the form of ferrous fragments. Additional shovel tests were added at 10 meter intervals to the north and the south until no archaeological materials were encountered. This increased the total number of shovel tests in this segment of the survey to nine. Of the nine shovel tests excavated, four (44\%) produced cultural material. The artifacts collected from these shovel tests included lithic flakes, rusted metal, and slag. The four positive shovel tests located within 10 meters of each other meet the qualifications for designation as archaeological site 41GL411 (Figure 5-1). Site 41GL411 is multi-component, with both prehistoric and historic material recovered. None of the artifacts are diagnostic and cannot firmly place either component of the site to a specific period or date. In addition, the positive shovel tests are located in a portion of the APE crossed by an old river channel. Therefore, it is possible that the material was washed in during flooding episodes. The site does not have potential for producing significant buried intact deposits. In addition, the recovered materials have little to no research potential.

\section{Recommendations}

Construction associated with the improvements and relocation of the two park roads is eminent. Archaeological investigations identified one new site during the course of the project, found two Isolated Finds, and confirmed that site 


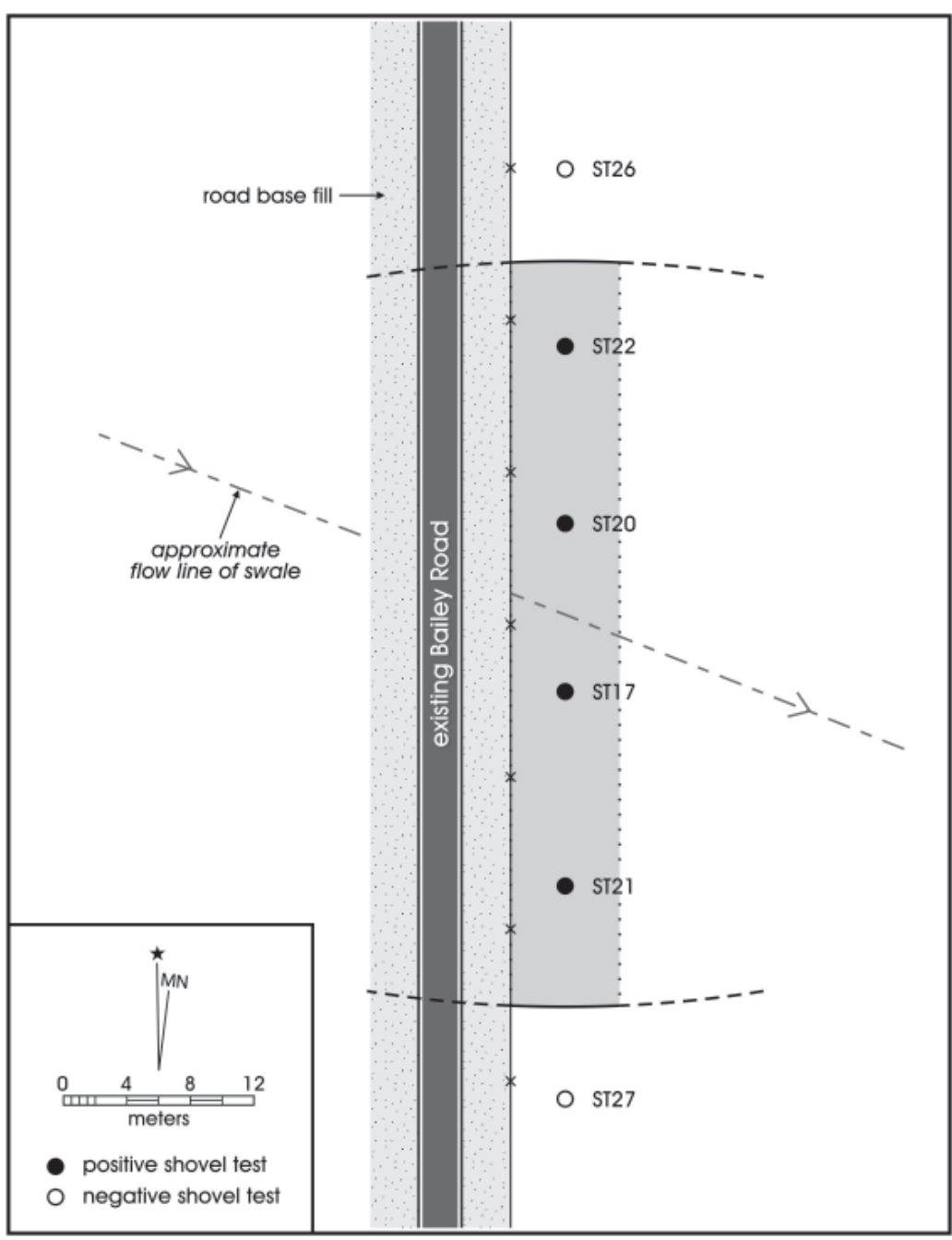

41 GL319 extended to the road. Site 41GL411 appears to have no potential for producing significant intact deposits. CAR recommends that the site is neither eligible for listing on the NRHP nor formal designation as SAL and does not recommend any further investigations of this site.

The linear survey of the project area found no significant deposits that would require the planned improvements and relocation of the roads to be altered. CAR recommends no further investigations along the APE and suggests that the proposed improvements should proceed as planned.

Figure 5-1. Site map of 41 GL411 adjacent to Bailey Road. 


\section{References Cited}

Bement, L.C.

1991 The Thunder Valley Burial Cache - Group Investment in a Central Texas Sinkhole Cemetery. Plains Anthropologist 36(135):97-109.

Black, S.L.

1986 The Clemente and Herminia Hinojosa Site, 41 JW 8 : a Toyah horizon campsite in southern Texas. Special Report No. 18. Center for Archaeological Research, The University of Texas at San Antonio.

1989 Central Texas Plateau Prairie. In From Gulf Coast to the Rio Grande: Human Adaptation in the Central, South, and Lower Pecos Texas, edited by T.R. Hester, S.L. Black, D. G. Steele, B.W. Olive, A.A. Fox, K.J. Reinhard and L.C. Bement, pp. 17-38. Research Series No. 33. Arkansas Archeological Survey, Fayetteville.

Black, S.L., L.W. Ellis, D.G. Creel and G.T. Goode

1996 Hot Rock Cooking on the Greater Edwards Plateau: Four Burned Rock Midden Sites in West Central Texas. Studies in Archaeology, No. 22. 2 vols. Texas Archaeological Research Laboratory, The University of Texas at Austin.

Bousman, C.B.

1998 Paleoenvironmental Change in Central Texas: The Palynological evidence. Plains Anthropologist 43(164):201-219.

Bousman, C.B., B.W. Baker and A.C. Kerr

2004 Paleoindian Archeology in Texas. In The Prehistory of Texas, edited by T.K. Perttula, pp. 15-97. Texas A\&M University Press, College Station.

Collins, M.B.

1995 Forty Years of Archeology in Texas. Bulletin of the Texas Archeological Society 66:361-400.

2004 Archeology in Central Texas. In The Prehistory of Texas, edited by T.K. Perttula, pp. 205-265. Texas A\&M University Press, College Station.

Foster, W.C.

1995 Spanish Expeditions into Texas 1689-1768. University of Texas Press, Austin.

Fox, A.A. and D.E. Fox

1967 Test Excavations at The Classen Rockshelter, Northeastern Bexar County, Texas, 1967. La Tierra 7(1):16-23.

Hester, T.R.

1995 The Prehistory of South Texas. Bulletin of the Texas Archeological Society 66:427-459.

2004 The Prehistory of South Texas. In The Prehistory of Texas, edited by T.K. Perttula, pp. 127-151. Texas A \& M University Press, College Station.

Highley, C.L., C. Graves, C. Land and G. Judson

1978 Archaeological Investigations at Scorpion Cave (41ME7) Medina County, Texas. Bulletin of the Texas Archaeological Society 49:139-194. 
Huebner, J.A.

1991 Late Prehistoric Bison Populations in Central and Southern Texas. Plains Anthropologist 36(137):343-358.

Johnson, L., Jr.

1991 Early Archaic Life at the Sleeper Archaeological Site, 41 BC65 of the Texas Hill Country Blanco County, Texas. Publications in Archaeology, Report No. 39. Texas Department of Highways and Public Transportation. Highway Design Division, Austin.

Johnson, L., Jr.

1994 The Life and Times of Toyah-Culture Folk: The Buckhollow Encampment, Site 41KM16, Kimble County, Texas. Office of the State Archeologist Report 38. Texas Department of Transportation and Texas Historical Commission, Austin.

Johnson, L., Jr. and G.T. Goode

1994 A New Try at Dating and Characterizing Holocene Climates, as well as Archaeological Periods, on the Eastern Edwards Plateau. Bulletin of the Texas Archaeological Society 65:1-51.

Kalter, A.J., R.M. Rogers and M.N. Smith

2005 Analysis and Reporting for 41FY135, the Sandbar Site, Fayette County, Texas. PBS\&J, Document No. 020388. Archeological Studies Program Report No. 73. Environmental Affairs Division. Texas Department of Transportation. Austin.

Largent, F.B. Jr., and M.R. Waters

1999 The Distribution of Folsom Points in Texas. Current Research in the Pleistocene 7:27-28.

Long, C.

1996 Lyndon B. Johnson National Historical Park. In The New Handbook of Texas, edited by R. Tyler, pp. 348. Texas State Historical Association, Austin.

Mauldin, R.P. and D.L. Nickels

2001 An Archaeological Survey of Twin Buttes Reservoir, Tom Green County, Texas. Archaeological Survey Report No. 300. 3 vols. Center for Archaeological Research, The University of Texas at San Antonio.

Mauldin, R.P., D.L. Nickels, and C.J. Broehm

2003 Archaeological Testing to Determine the National Register Eligibility Status of 18 Prehistoric Sites on Camp Bowie, Brown County, Texas. Archaeological Survey Report, No. 334 Volume 1. Center for Archaeological Research, The University of Texas at San Antonio.

McKinney, W.W.

1981 Early Holocene Adaptations in Central and Southwestern Texas: The Problem of the Paleoindian-Archaic Transition. Bulletin of the Texas Archeological Society 52:91-120.

Munoz, C.M.

2004 Native American Adaptation on the Texas Coastal Plain: A Study of the Dentition from Thirteen Prehistoric and Historic Cemetery Sites. Unpublished Master's Thesis, Department of Anthropology, The University of Texas at San Antonio.

National Park Service (NPS)

2009 Lyndon B. Johnson National Historical Park. http://www.nps.gov/lyjo/index.htm. Accessed September 2009. 
National Register of Historic Places (NRHP)

1990 National Register of Historic Places Registration Form for Lyndon B. Johnson National Historical Park. On file at the Center for Archaeological Research.

Nickels, D.L., R.J. Hard and C.B. Bousman

1998 Test Excavations at the Culebra Creek Site, 41BX126, Bexar County, Texas. Archeological Studies Program Report No. 3, Texas Department of Transportation. Environmental Affairs Division, Austin. Archaeological Survey Report, No. 265. Center for Archaeological Research, The University of Texas at San Antonio.

Patterson, L.W.

1988 Chronology of Arrow Point Types in South Texas. La Tierra 15(4):29-33.

Prewitt, E.R.

1981 Cultural Chronology in Central Texas. Bulletin of the Texas Archaeological Society 52:65-89.

1983 From Circleville to Toyah: Comments on Central Texas Chronology. Bulletin of the Texas Archaeological Society 54:201-238.

Quigg, J.M., C. Lintz, F.M. Oglesby, A.C. Earls, C.D. Frederick, W. N. Trierweiler, D.W. Owsley and K.W. Kibler 1993 Historic and Prehistoric Data Recovery at Palo Duro Reservoir, Handford County, Texas. Technical Report 485. Mariah Associates, Inc., Austin.

Ricklis, R.A.

1995 The Ceramics of the Toyah Horizon and the Rockport Phase as Indicators of some Basic Sociocultural Patterns. Bulletin of the Texas Archaeological Society 66:195-203.

Tyler, R.

1996 Lyndon Baines Johnson Birthplace, Boyhood Home and Ranch. In The New Handbook of Texas, edited by R. Tyler, pp. 349. Texas State Historical Association, Austin. 
